\title{
Transmigration Area Development and Its Community In Indonesia
}

\author{
*Santun R.P. Sitorus \\ Department of Soil Science and Land Resource, Faculty of Agriculture, \\ Bogor Agricultural University (IPB), Meranti Street, IPB Dramaga Campus. \\ Bogor 16680, Indonesia. Phone/ Fax : (+62 251) 8422322 \\ Email: santun_rps@yahoo.com; santun_rps@apps.ipb.ac.id
}

*Corresponding Author, Received: March 10, 2019, Revised: April 10, 2019, Accepted: June 10, 2019

This is an open acces article distributed under the Creative Commons 4.0 Aftribution License, wich permits unrestricted use, Distribution, and reproduction in any medium provided the original work is properly cited @2017 by author and Universitas Negeri Padang

\begin{abstract}
Since the beginning, the great idea of transmigration program has actually been directed towards exploiting, processing and development of the two major potential resource, namely: (1) the potential of natural resources and (2) the potential of human resources. Since its implementation, the transmigration program has shown success in improving the living standards and welfare of the population and the development of previously untapped areas,although in some locations and regions it also shows the lack of success caused by various problems. At least there are three major domains of transmigration areas and community development in the future, namely: (1). Develop undeveloped regions into new productive and growing areas in accordance with its natural resource potential including New Transmigration Settlements (PTB) and New Integrated Self-establishment City (KTM). (2). Developing the existing transmigration area becoming the new growth centers of the region through the development of Integrated Self-establishment City (KTM). (3). Improving the welfare of smallholders and poor farm workers through the provision and control of production assets (land). Community and transmigration areas development in the future should be based on 5 basic principles, those are : (1). Development of land and human resources. (2). Development of sustainable agriculture system.(3). Development of business activities based on agribusiness range.(4). Development of private participation, cooperatives, State Owned Enterprises (BUMN) and individual farmers. (5). Integrated area development. Investment in physical development and institutional innovation in development of transmigration areas should be done gradually by following the stadia of regional development which generally consists of: Stadia I, II, III, IV, V, VI. There are two conditions that can be realized through development of transmigration areas in the future, namely: (1). First, to realize a more equally and equitable development.(2). Second, to realize a competitive nation. At least six policy direction in the construction and development of society and transmigration areas in the future.First, pay particular attention to the elements of the development of the competitiveness of the region. Second, strengthening the new orientation to provide support to: (a) Increased public income, (b) food security and board needs, (c) Creation of employment opportunities.Third, the mainstreaming of Integrated Self-Establishing City (KTM) from the planning process to the development of the area. Fourth, focusing and prioritizing the development of communities and transmigration areas. Fifth, enhancing cross-sectoral and local government participation in the planning and implementation of development of communities and transmigration areas. Sixth, increasing community independence in transmigration area.
\end{abstract}

Keywords: Basic Principles, Integrated Self-Establishing City, Policy Direction, Stadia of Regional Development. 


\section{Introduction}

The migration of the population behind the development of transmigration areas in early independence is actually a shared awareness to utilize, process, and develop all the potential resources of the Indonesian Nation. Since the beginning, the great idea of transmigration program has actually been directed towards exploiting, processing and development of the two major potential resource, namely: (1) the potential of natural resources and (2) the potential of human resources. However, it is the selection of priority in managing and developing the potential of these resources is in fact not an easy thing. In the initial scenario until 1972, transmigration development focused more on the migration aspect of Java-Bali-Lombok Islands to manage and develop the potential of natural resources outside Java-Bali-Lombok Islands. The focus on this aspect of population movement is also stated in Article 2 of Law No. 3 of 1972 on Transmigration Principal Provisions which is then amended in Law no. 15 of 1997 and Law no. 29 of 2009 on amendment to Law no. 15 of 1997 on transmigration.

Since its implementation, the transmigration program has shown success in improving the living standards and welfare of the population and the development of previously untapped areas. (Hermon, 2001; Iskandar, 2009). In addition to these successes, in some locations and regions it also shows the lack of success caused by various problems. In the future development of transmigration areas, these two things successful and less success locations with the various problems need to be considered in order that the success of development of transmigration areas in the future in various changes of strategic environment can be further improved. The implementation of transmigration has provided a significant contribution to national development. Until now, the locations of the transmigration settlements that have been built have grown to 104 new distric capitals / cities, 383 have become sub-district capitals and from a total of 3055 villages which were built 1,183 transmigration settlements became definitive villages and the rest became part of local villages (Directorate General of Area Preparation and Transmigration Settlement Development, 2015; Hermon et al., 2018).

Indonesia's economy is inseparable from the turmoil of the global strategic environment that continues to grow dynamically, such as the emergence of Asia Pacific as a new economic power and a potential market for agricultural products in the future. Geographically, Indonesia is located in a favorable strategic position compared to many other supplier countries for this region (Hermon, 2019). The challenges facing the transmigration program to remain a role as a driver of national economic development and still able to compete in the international market can be answered if the development of transmigration regional products market-oriented (Sardjadidjaja, 2005; Hermon, 2009). Correspondingly, efforts to improve technical and economic efficiency will emerge by itself. This increasingly complex and competitive economy demands a high level of efficiency. Consequently, inefficient efforts will naturally be displaced or at least will not compete in a highly competitive market, both local and international markets. A shift toward efficiency requires the use of advanced technology, managerial capabilities and professionalism in the management of business activities.

This situation will clicking the increased ability to master and use of science and technology as well as the preservation of the competitive advantages that have been owned. Thus, the role of technology and business information becomes very important. Technology, business and market information with its various characteristics become a component in production and marketing activities ranging from macro to micro levels. International markets information for agricultural commodities on the quantity and quality requested, the prevailing price, location, transportation, financial support, the exchange rate of the competing countries is necessary, either by the parties involved in decision-making, planning and exporter. At the micro level, information on the number, time, place or quality of products, and managerial information in conducting business activities related to administration and production costs are increasingly required to achieve high levels of efficiency.

Development of communities and transmigration areas is an effort to disseminate development with the utilization of human resources and natural resources in order to realize a tough and efficient agriculture and develop the most supportive economic system and strengthen the interconnection with other economic sectors (Hermon, 2012). As a country with an open economic system and with a considerable share of international trade, the development of globalization causes the Indonesian economy to be more closely related to the development of the world economy. The ability to be able to efficiently and effectively dampen 
the impact of social unrest, economic and political world against national economic development as an indicator of the resilience of the national economic system to remain and take advantage of globalization.

In the process of structural transformation of the Indonesian economy, the transmigration sector is required to remain capable of supporting the sustainability and harmony of national economic development. In this framework, the linkage with other sectors, among others, through the integration of agribusiness development needs to be improved so that the fulfillment of the needs of the food, the raw materials of home industry, and exports in the quantity, quality and continuity appropriate to the changing market demand should always be met.

On the local side, there is the impression that now arises dichotomy between the cycle of poverty and luxury circles that if not formulated in a policy that fosters partnership and interdependence and mutual support, then the sustainability of development may be deterred. The circle of poverty and the circle of luxury is not something that happens by itself. From observation in the micro level, it is seen that the rural push symptom, as a result of the displacement of smallholders and farm laborers from land tenure and ownership structures is accompanied by very limited work opportunities outside agriculture and urban migration, as a result of the rapid growth of urban industry is not an event that can be cited as a natural consequence of development, since those who profited in the city in fact largely did not work in the industrial sector or the service sector but instead worked in the informal sector.

At least there are three major domains of transmigration areas and community development in the future, namely: (1) Develop undeveloped regions into new productive and growing areas in accordance with its natural resource potential (agent of development) including New Transmigration Settlements (PTB) and New Integrated Self-establishment City (KTM) . These activities along the way will assist in developing regional development equally of the areas with less balanced development, (2) Developing the existing transmigration area becoming the new growth centers of the region through the development of Integrated Self-establishment City (KTM), and (3) Improving the welfare of smallholders and poor farm workers through the provision and control of production assets (land).

Three aspects of the above activities are activities that have not been handled specifically by various other technical agencies. Therefore, in my view the development of transmigration areas in Indonesia is still relevant and indispensable (Hermon, 2010; Hermon, 2011). The three main domains will have different activities and achievement goals, so that the success of development of transmigration area can no longer be arranged in the form of a success criteria for various activities of implementation because in fact each activities has different targets and measures of success. Success of community development and transmigration area development can be seen from the extent to which migrants can utilize natural resources (land and water) are given for the purpose of earning that income and household welfare of migrants increased continuously. In this connection, in the future the implementation of transmigration settlement pattern with certain principal business activities that have been very tight and determined in advance has to be relaxed with the determination of the pattern of main business (main commodity) adjusted to the potential and suitability of land resources and the needs of local and regional markets and supporting commodities, so that it can create optimization of land use in the transmigration area.

\section{Basic Principles in Community and Transmigration Area Development in The Future}

Community and transmigration areas development in the future should be based on 5 basic principles, those are: (1) Development of land and human resources, (2) Development of sustainable agriculture system, (3) Development of business activities based on agribusiness range, (4) Development of private participation, cooperatives, State Owned Enterprises (BUMN) and individual farmers, and (5) Integrated area development. In the past, recruitment and an employment chooser on transmigration projects development tend to be mechanistic in the sense of giving priority to quantity. In addition, the recruitment of workers only prioritizes less skilled labor. In the future, the recruitment and development of manpower should be functional. Recruitment of manpower does not exceed the amount required to perform the management functions.

Operational experience and research results for morethan three decades provide a strong indication that in essence the land ecosystem in the transmigration area is able to support a dynamic modern farming 
system. Nevertheless, some of the dynamic properties of land ecosystems in transmigration areas , especially soil and water components need to be carefully considered. The first thing that needs to be noticed especially in wetlands is the dynamics of soil acidity properties in relation to water management whereas in dry land soil acidity, soil fertility and slope (Sukmana, 1995; Kurnia, 2001; Sitorus, 2002). More specifically, soil chemical properties requiring integrated management are: (1) the dynamics of soil acidity properties in relation to the management of the water regime (Suriadikarta and Setyorini, 2006; Hermon, 2014; Hermon, 2015), (2) the dynamics of nitrogen fertility and soil phosphorus, and (3) the dynamics of micro nutrient fertility, especially $\mathrm{Zn}, \mathrm{Cu}$ and Mo (Ismail et al. 1993; Yusuf et al. 1995). In addition, the management of soil physical properties, especially those related to the phenomenon of subsidence, needs attention(WidjajaAdhi and Alihamsyah, 1998). Some of the functions of management of land and water that need attention are: (1) land and water management must be the unity in an integrated manner (Sinukaban, 2007; Hermon, 2016; Hermon, 2017; Oktorie, 2017), (2) the plan of land and water management must include the horizon planners at least the medium term (five years), (3) operational management functions should be as flexible as possible to accommodate unexpected dynamics, and diversity of dynamics between areas, and (4) operational functions based on the management of the area.

The sustainability of a system essentially contains three main dimensions: (1) biological-physical sustainability, (2) economic sustainability, and (3) socio-cultural sustainability. In relation to the physicalbiological sustainability dimension, the horizon of transmigration area development planning must include an infinite time horizon. The sustainability of a dynamic system of nature is a phenomenon that can not be denied. Therefore, changes in the natural ecosystem of land in the transmigration area can only be done if those changes provide tangible benefits to the welfare of the population. In addition, development management of transmigration areas as far as possible should avoid changes that are irreversible and the changes that threaten diversity (biodiversity) of natural ecosystems (Hermon et al., 2017).

Most of the development of transmigration areas in the past is based on a partial and overly-favored concept of production sub-systems. In the future, with the emergence of new opportunities and challenges due to economic globalization and transformation of the national economic structure, should be in the development of transmigration areas, the concept of agribusiness can be applied in full. Plans and implementation of transmigration development should include four subsystems, namely: (1) procurement of production factors, (2) production, (3) post-harvest and agro-industry, and (4) distribution and marketing, in an integrated package. Although in some cases the whole subsystems can not be built simultaneously but investment activities, both government and private, should be implemented on the principle: if a subsystem is developed, there is a guarantee that other subsystems are available for investment funds in order to benefit the community.

Although the processing of agricultural products has begun to develop but its impact on the economy of transmigration area has not felt optimum. Agro industry that develops in transmigration area is still relatively rare and if there is still tend to be traditional, household scale, and spread in small business unit. While agro-industries using advanced technology, capital-intensive and large-scale that are generally located in urban areas do not have a large double effect on the economy in the transmigration area. The challenge faced in developing agro industry is that these activities must be developed in the transmigration area by using technology that is able to absorb more relative labor and can be run according to the expertise of the local population. With this approach agro-industry activities will be able to generate economic activities in the transmigration area, increase labor productivity, and increase the income of transmigration.

Marketing activities of agricultural products is one of the subsystems in agribusiness which is considered as the weakest point. It is often said that marketing of agricultural products is inefficient and thus one of the causes of high cost economics in agricultural trade and exports. The main causes of this situation include agricultural production scattered in small units and relatively remote locations, post-harvest handling is not perfect, and the lack of standardization and production capacity in accordance with expected commodity standards. Another problem is the insufficient availability of facilities for marketing and transportation infrastructure needed in agricultural production centers in transmigration areas. The challenge faced in fostering the marketing of agricultural products in the transmigration area is to make this activity an efficient activity. Marketing of agricultural products should be able to stimulate overall agricultural activity and provide fair returns to every economic actor involved in each subsystem in the marketing sequence. 


\section{Development of Private Participation, Cooperatives, State-Owned Enterprises (BUMN)and Individual Farmers}

Institutional deregulation leading to a business climate that enables the development of healthy competition mechanisms and mutually beneficial cooperation among economic actors is one of the conditions of successful development of transmigration areas in the future. Healthy competition and mutually beneficial cooperation can drive the improvement of productivity and efficiency of the national economic system. Increased productivity and efficiency is the main performance that determines the success of Indonesia in the era of economic globalization. Much of the investment in the development of transmigration areas in the past has been carried out by the government with general aims. In the future, in the development of transmigration areas, the participation of all economic actors, either individually or collectively, is needed. Therefore, strategies that contain elements of carrot (subsidy) and stick (tax) policy is needed. Incentives for private sector involvement, cooperatives, state-owned enterprises and individual farmers include but are not limited to subsidies in: (1) infrastructure development, (2) assurance of production prices, (3) institutional development, (4) product price guarantees, and (5). Taxreduce. Besides, investment disinsentive in other areas such as through permits or local taxes can be encouraged to develop transmigration areas.

Transmigration area development unit may include areas that have already been opened but require further development or new development areas. Businesses Enterprises that become the main investors are private, state-owned and cooperative, either individually or in cooperation with each other. In these efforts community participation as a condition that must be met. The function of government is to encourage the participation of business entities, for example through infrastructure and socio-cultural development, specific subsidies and taxation policies. In each transmigration region developed a major commodity and some supporting commodities. In some cases, the agribusiness development unit is not a continuous area, so the development of an efficient transportation infrastructure system can make the area an efficient unit. The main commodities in a development unit are set based on the principle of competitive advantage. Supporting commodities are developed with the aim of: (1) exploiting the diversity of land resources, (2) reducing risk and business uncertainty, (3) utilizing labor force fluctuations in a more optimal direction, and (4) utilizing complementary properties of commodities in agro-industry development.

Regional development need to consider alternatives to agribusiness systems development which includes procurement of factors of production, production, post-harvest, agro-industry and marketing. Development of regional infrastructure needs consider the type and range of agribusiness to be developed. For example, the development of drainage and water supply systems from the beginning needs to be tailored to the commodities to be developed. The size of the area to be developed needs to take into account the economic scale of the business and the capacity of the industrial machinery to be used. Agribusiness development unit needs to be integrated with the area around it through: (1) the development of the transport system and telecommunications functional, (2) institutional innovation that effectively bridging unit agribusiness development with the community and the market around it and, (3) development of service centers and growth that has a hierarchy integrated with existing service centers and growth. The type and number of infrastructure and service facilities built at each service center (including KTM centers) needs to be adjusted to : (1) commodity type, (2) range and scale of agribusiness to be developed, and (3) regional economic development stage.

Investment in physical development and institutional innovation in development and development of transmigration areas should be done gradually by following the stadia of regional development which generally consists of: (1) Stadia I. Stadia pre-subsistence, where the community has not been able to meet its basic needs. Therefore, grants or subsidies for basic needs are required, (2) Stadia II. Stadia subsistence, the community has been able to meet its basic needs. Therefore, infrastructure and institutions must be developed to increase the chances of efficient family exchanges, (3) Stadia III. Stadia market surplus, where the community in addition has been able to meet basic needs, has also been able to produce for local markets or regional markets. At this stage strategic action that needs to be done is to encourage the development of transactions between markets and encourage basic activities of agro-industry development, (4) Stadia IV. Stadia agro industry, where economic development has reached a state where agricultural activities have been able to produce a sustainable, regular and quality surplus of markets that meet the requirements as 
inputs on agro-industries, (5) Stadia V. Stadia secondary industry. The development of agro industry has been able to increase the income of society in real (substantial). The increase in revenue resulted in increased public demand for secondary industrial commodities such as processed foods, flip-flops, textiles, and so on. This situation will attract secondary industries to come to the region, and (6) Stadia VI. Stadia services. The development of secondary industries is expected to increase people's income. Furthermore, the increase will lead to an increase in public demand for services. This situation will attract development investment of service industries to transmigration areas.

Experience shows that the chances of successful development and development of communities and transmigration areas are greater in areas where the development of economic structures is relatively more developed. This is mainly due to: (1) dynamic business climate provides greater and diverse business opportunities thereby reducing risk and uncertainty, (2) realization of the potential backward linkage and forward linkage faster and (3) relatively large and stable local demand, and (4) relatively more developed infrastructure enabling business efficiency improvements.

\section{Opportunity and Growth Source for The Development of Transmigration Area and its Community in The Future}

Economic growth in general and transmigration programs in particular are highly dependent on the availability and quality of natural and human resources, the mastery of science and technology, and the ability to handle other biophysical and socio-economic aspects. During the new order period the overall transmigration program has played a significant role in the equitable distribution of development and national economic growth through the growth of production centers. The robustness of the transmigration program will remain a very important factor in national development given its role as an employer absorber, suppliers of foodstuffs and industrial raw materials, and sources of foreign exchange.

At this time there are still some factors and resources that have not been utilized optimally. If these circumstances and factors can be improved, the development of transmigration areas will remain capable of sustaining the development of the national economy. Potentials that have not been utilized include:

1. There is a gap between the real productivity and the potential productivity of various agricultural commodities, so that the increase of productivity can still be done through the improvement of farming technology and socio-economic engineering.

2. There are agricultural area and other business land in transmigration area that has not been utilized optimally and also water area with low utilization rate. The potential can be developed to increase the production and income of communities in the transmigration area.

3. Agriculture product in transmigration areas are generally still poor quality, thus enhancing the quality can be used as a source of growth that can increase the value added.

4. Loss and post-harvest damage is still quite high. This loss can be suppressed in an effort to increase production through improved harvest and post harvest technology.

5. The use of agricultural products is increasingly diverse, not only for direct food and exports, but also for domestic raw material of industry and livestock feed stocks. Diversification of product use is a source of growth that can drive production through increased demand for agricultural processed products.

6. There is still a lack of incentives to attract investment to the transmigration area, mainly due to the lack of conformity to the macroeconomic climate, such as interest rates, international trade situation, and risk reduction in agribusiness.

Based on the points mentioned above, the sources of growth for the future development of transmigration areas can be grouped into four groups:

1. Sources of growth associated with increased production and productivity such as intensification , diversification and application of cultivation technology that can improve technical and economic efficiency.

2. Sources of growth related to the increase of added value, namely improving the quality of the products of basic business activities and their processed products and the exploitation of high value economic crops. 
3. Sources of growth derived from the excavation of demand potential, among others, by increasing demand through the diversification of product use, processing and marketing.

4. Institutional growth sources, such as the creation of a business climate that encourages investment, the continuity of mutually beneficial relationships between functional activities in the agribusiness system, and efforts to emphasize risks and costs of production.

Development of transmigration areas and its community in the future should refer to the Act of the Republic of Indonesia Number 29 Year 2009 on Amendment to Act Number 15 Year 1997 on Transmigration. The consequences of the implementation of Act no. 29 of 2009 requires a re-orientation or shift of orientation from the original form of resettlement to support regional development into the development of areas that impact on population mobility as in Figure 1.
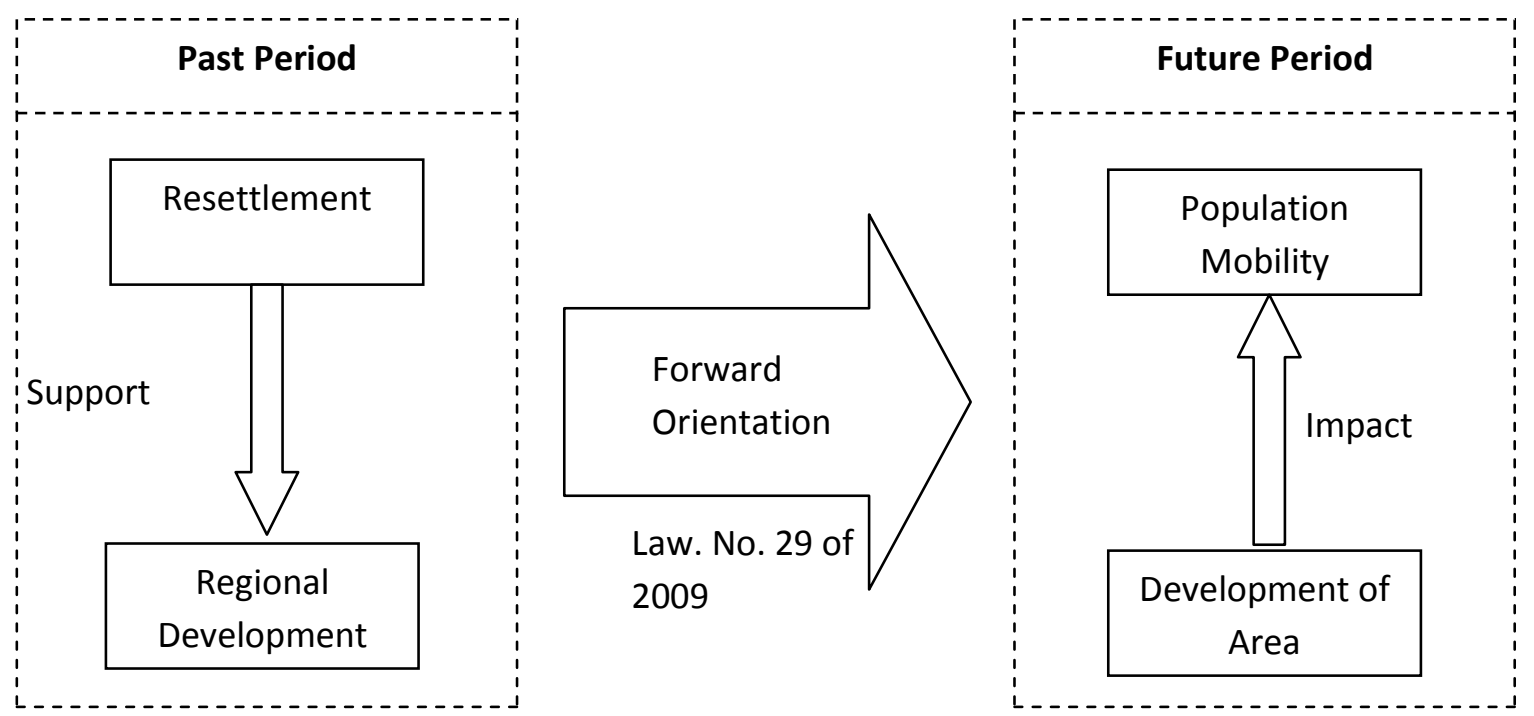

Figure 1. The Shift in Development Orientation and Transmigration area Development in The Future

There are two conditions that can be realized through development and development of transmigration areas in the future, namely: First, to realize a more equally and equitable development. Equally development and can be enjoyed by all components of the nation in various parts of Indonesia will increase the active participation of the community in development, reduce the disturbance of security, and eliminate the potential for social conflict to achieve a prosperous, independent and fair Indonesia. Second, to realize a competitive nation. This condition becomes very important, because the competitiveness of the nation is the key to achieving the progress and prosperity of the nation. With high competitiveness, we will be ready to face global challenges and be able to take advantage of opportunities. In line with the direction of national development, the expected future condition is the realization of a transmigration area capable of producing goods and services efficiently in accordance with market needs. Under these conditions, the transmigration area is ready to face regional, national and global challenges and be able to take advantage of existing potentials and opportunities. Pre-requisite for the development of society and transmigration areas is forward transmigration development should be directed to: (1) promote development of human resource migrants and their communities become more qualified as the capital of the face of increasingly fierce competition, (2) strengthen regional economy based on local advantages to competitive excellence to establish linkage system of production, distribution, and market, (3) improving the acquisition and utilization of knowledge and appropriate technology, (4) build adequate infrastructure in accordance with the major commodity to be developed, and (5) Conduct improvement of transmigration candidate recruitment and settlement development integrated with improvement of local settlement.

Thus, the conditions of transmigration human resources (transmigration) and local communities need to be the focus of attention. Strengthening human resource capacity necessary to support the business 
development of economic systems based democratic economy through community empowerment, which is based on the development of resource potential and diversity of the cultural wisdom. In addition, sociocultural development should be directed to realize a harmonious and balanced population distribution with the carrying capacity of nature and the capacity of the environment.

Some input and thought which can realize both of these conditions are described below: First, voters of resettlement area based on the potential advantages of natural resources and sustainable development principles. The main purpose of the development of transmigration areas is the improvement of the quality of life and the welfare of society and its equity. Implementation of development of the region is done in a planned and integrated with all sector development plans. Second, economic activity in the transmigration area is encouraged synergy. In this case, the production of rural areas is a backward linkage of economic activity in the center of growth that forms a system of economic development areas. Such increased linkages require the expansion and diversification of economic and trade (non-agricultural) activity in rural areas linked to the market at the center of growth. Therefore, since the beginning of the economic development in the transmigration area should provide greater opportunities to the Enterprise as a partner of transmigration community that is equal and responsible. Thirdly, Growth Center in the transmigration area developed through the development of Integrated Self-Establishment City (KTM) should be able to act as the driving force for the development of the surrounding areas and in serving the needs of the people in the region. (Iskandar, 2010). Therefore, the development of KTM must be implemented holistically and comprehensively by integrating various activities in the region scale into one unified economic territory. In this context, the construction and development of KTM can be implemented via two approaches, namely: (1) undertake further development of existing transmigration settlements integrated with the surrounding area that has a certain economic scale into the KTM area (2) develop new transmigration areas designed in a unified region integrated with the surrounding area that has a certain economic scale into the KTM area . In its development hereinafter referred to as transmigration areas. Until now, Minister of village, underdeveloped region development and transmigration have set transmigration areas with 7 consecutive ministerial decrees. Those are ministerial decree number 9 of 2016, number 91 of 2016, number 104 of 2017, number 118 of 2017, number 71 of 2018, number 16 of 2018, and number 115 of 2018 concerning the establishment of transmigration areas. With the 7 ministerial decrees, 140 transmigration areas have been appointed in Indonesia.(Minister of village, underdevelopped region development and transmigration $(2016 ; 2017 ; 2018)$. Fourth , transmigration areas are built to support food security that is capable of ensuring adequate food supply at the household level, both in quantity, quality, security, and affordable prices, supported by diverse food sources in accordance with local diversity. The phenomenon of the conversion of wetland (rice) to other higher value (palm and rubber) commodities recently in various transmigration areas of food crops, including most of the KTM areas, needs to be taken seriously. For that there should be restrictions for at least 0.5 ha paddy fields need to be maintained so that the food needs of transmigration families can be met from the results of farming itself. In addition, the development of transmigration areas in accordance with their respective potentials and advantages needs to be developed into tropical agricultural products that are able to meet the needs of regional and international markets such as rice, coffee, chocolate, cashew, sugar cane, corn, rubber, white pepper, black pepper, nutmeg, palm oil, cloves, tea, essential oil, tropical fruits, and others. Fifth, the transmigration area is built through the development of agribusiness chain with labor-intensive agro industry, especially for the area based on the agriculture and marine business. Sixth, cooperative/microfinance institutions are encouraged to develop according to needs as be an effective vehicle to improve the bargaining position of its members, both producers and consumers. Meanwhile, the empowerment of micro enterprises is encouraged to increase the income of low income groups in order to reduce the income gap. Seventh, inter-regional cooperation should continue to be encouraged and developed to harness the comparative and competitive advantages of each region, which can gradually build togetherness and avoid inefficiencies in public services. Inter-regional cooperation in the implementation of transmigration should be positioned as an entrance to various forms of cooperation that can be developed in inter-regional economic, social and cultural cooperation so that in turn it will build inter-regional networks with respect for their respective autonomy. Thus, the cooperation of transmigration can also serve as a medium of integration of inter-regional interests within the framework of national interests. 
The active participation of the community needs to be improved in every transmigration program developed, from the planning stage, the arrangement of the developed area candidates, to the stages of development of the community and the region, so that the community considers that transmigration is a strategic program to manage and develop the resource potential so that it can be believed promote mutual prosperity. The transmigration area that is developed holistically and comprehensively is expected to be able to build growth centers as a buffer city for the regencies or municipalities outside Java Island, which absorb a considerable labor force, both local and labor from other regions. The relationship of interdependence and mutual need between the Destination Region and the Origin is increasingly felt, so that cooperation between regions becomes a common need. Thus the Government's diminishing role is decreasing, while the role of Business Entity in moving the region's economy is getting bigger.

\section{Policy Directions of Transmigration Area and Its Community Development in The Future}

At least six policy direction in the construction and development of society and transmigration areas in the future that need to be developed consistently based on a shift in orientation as set out in previous Chapter. First, pay particular attention to the elements of the development of the competitiveness of the region by: (a) prioritizing the linkages of production, processing, and markets or upstream in the form of inter-regional linkages based on local superior products; (b) prioritizing destination area based on resource capability and the prospect of integrated regional development, and (c) prioritizing target areas of prospective transmigration sources based on the need for resolving population problems in the recruitment of prospective transmigration. Secondly, strengthening the new orientation to provide support to: (a) Increased public income, (b) food security and board needs, (c) Creation of employment opportunities and expansion of employment opportunities for the unemployed and poor, (d) Equitable investment equity become the driving force of the regional economy, (e) Provision of alternative energy raw materials, (f) National resilience. Third, the mainstreaming of Integrated Self-Establishing City (KTM) from the planning process to the development of the area, both within the framework of the development of existing transmigration areas and in the development of new areas. Fourth, focusing and prioritizing the development of communities and transmigration areas to accelerate the development of strategic areas and rapid growth, underdeveloped areas, and border areas. Fifth, enhancing cross-sectoral and local government participation in the planning and implementation of development of communities and transmigration areas through improvement of: (a) quality of human resources, (b) Bappeda's role as planning coordinator between activities and inter-actors , and (c) involvement of across sectors in the planning and development of public facilities and social facilities in the transmigration area. Therefore, inter-regional service and mediation need to be continuously improved in inter-regional cooperation consistently and responsibly. Sixth, increasing community independence in transmigration area through: (a) information service of potential superior product, (b) improvement of understanding on agribusiness system and investment development prospect, and (c) increasing ability to face dynamic cooperation of partnership increasingly complex.

In principle, alternative development strategies and community development and transmigration areas proposed is the development of transmigration areas with a sustainable integrated agribusiness systems approach. Transmigration area development direction in general is to realize a strong transmigration area characterized by its ability in the welfare of the migrants and its ability to encourage the growth of the sector and the national economy as a whole. The main focus of development of transmigration area in the future is laying the foundation to improve the quality of human resources (transmigration) itself to qualified and highly productive human beings and make transmigration as one of the sectors that are relied upon in reducing poverty in the dynamics of development that is more advanced and complex. With this approach, the orientation of development of communities and transmigration areas is not only to increase the income of transmigration, but also to cover the whole system of agribusiness which is carried out in an integrated manner with attention to the sustainability of natural resources and environment. Implementers form is an integrated farming system with efficient economic of scale.

Based on the foundation and policy directions described earlier, the development goals of transmigration areas and its community in the future can be formulated as follows: (1) Increasing transmigration income through diversification of business activities with efforts to optimize the utilization of 
environmentally sound natural resources and increasing the value added of the results of business activities, (2) Encourage and improve the creation of employment and business opportunities in transmigration areas through the utilization of sectoral economic linkages in the agribusiness system, and (3) Encourage and improve regional development equity.

The basic strategy that can be developed is the development of transmigration area with the application of integrated agribusiness system continuously. In this basic strategy linkages and coherence in the implementation of transmigration areas development is absolutely necessary. Thus, one of the main keys to successful development of transmigration areas with this strategy is the harmonious integration and mutual support among sub-systems in the agribusiness system, between sectors in the national economic system, and between regions within the Indonesia intergovernmental order. Coordination and program synchronization with various parties (across sectors of local government and private sector) is absolutely necessary and needs to be improved. The application of the agribusiness system requires the readiness of human resources (transmigration) as the main actors (Hermon et al., 2019). To that end , the orientation of human resource development (transmigration) should be directed not only to its ability in farming, but also on its ability in the agricultural business. With this approach transmigration can be more critical in carrying out their economic activities, including in improving the efficiency of development resources and in anticipating market opportunities. Implementation of integrated agribusiness system strategy requires the implementation of environmentally sound transmigration area development which means the utilization of natural resources must always refer to the principle of efficiency, able to preserve the level of productivity, and at the same time can prevent the degradation of quality of natural resources and environment as early as possible. Environmental management activities in key business activities and the creation and application of conservation farming practices that considers environmental sustainability are two key factors for the success of this effort.

In line with the above strategies, the main efforts to develop transmigration areas that can be implemented include the following: (1) Development of intensification and diversification of core business activities and supporting business activities, (2) Strengthening rehabilitation of land resources, and (3) The development of economic democracy in the transmigration sector. All of the above basic efforts are implemented in order to improve transmigration image and improve the quality of transmigration resources. The latter is closely related to the increase in income of transmigration households, increased work productivity, work convenience, mastery and the application of agricultural science and technology, and the quality of food and nutrition consumption. Diversification of business activities should be directed to improve resource utilization optimization while maintaining its sustainability and broaden the spectrum of development of transmigration areas within a sustainable integrated agribusiness framework. To that end the notion of diversification of business activities should be expanded into a process of deepening and expanding the spectrum of transmigration areas development that include technology, resources, energy, labor, business opportunities, revenue, production, and markets. The implementation of this diversification does not mean simply changing the existing patterns of production and basic business activities for the efficient allocation of resources, but through market mechanisms and with due regard to the main priorities of national development.

The intensification of basic business activities is an effort to increase the productivity of labor and natural resources (rice fields, dry land, swamps, tidal lands, beaches and seas) with the application of science and technology packages and production facilities (energy, water, seed, fertilizer, pesticides) are efficient. With the development of environmentally sound transmigration areas, the technology packages assembled in the utilization of natural resources and production facilities need to be mixed into intensive technology packages that do not harm the environment, including those that are cost-effective in the use of organic and artificial fertilizers and pesticide production facilities. Rehabilitation of land resources is defined as the restoration of land resource productivity capability, both natural resources such as critical land, marginal land, degraded land, and irrigation infrastructure. The rehabilitation activities implemented within the framework of the implementation of environmentally sound development.

The application of economic democracy in the field of transmigration can be done through: (1) Increased quality of transmigration resources so that they can think critically in making the right decisions for their business activities, (2) Improved decentralization of development planning and implementation to 
encourage active participation of local communities, (3) Development of production by taking into account market mechanisms, optimizing the utilization of the region's natural resources, and the development of the entire agribusiness chain, (4) Development of business partners between various economic institutions by applying harmony and balance of risk and profit sharing in the family system between the Cooperative, BUMN and Private Company, and (5) Institutional development that can function in mobilizing and distributing funds, services and products of transmigration communities. Since this institution is very strategic in driving the economy in the transmigration area, its presence needs to be guaranteed by the regulation that this institution is managed and owned by the transmigration community.

Understanding agribusiness includes all activities ranging from procurement and distribution of means of production to the marketing of products produced by a farm. Thus agribusiness is a system consisting of: (1) Subsystem of procurement and distribution of production facilities, technology and development of agricultural resources, (2) Subsystem of agricultural production or farming, (3) Subsystem of post-harvest and processing of agricultural or agro-industry products, and (4) Subsystem of distribution and marketing of agricultural products.

Because this system is a continuous series of activities from upstream to downstream, the success of this agribusiness development depends on the availability of appropriate infrastructure and facilities and the progress that can be achieved on each node that becomes its subsystem. The effectiveness of the agribusiness strategy itself depends on the ability to describe it in a unified and harmonized policy and program between subsystems. Therefore, the concept and limitations of each subsystem need to be carefully determined, especially regarding its functional interconnection between subsystems in accelerating and increasing the flow of production and added value in an integrated commodity system.

The procurement subsystem and the distribution of the means of production covers the planning, management or the provision of means of production, technology and agricultural resources. Policies that strive for input to beavailable on time, in exact quantities, and appropriate types, appropriate quality and affordable by the purchasing power of transmigrants, is one of the first policies that characterize the existence of this subsystem. Meanwhile, the farming subsystem or production process includes the activities of fostering and developing farming activities in order to increase the primary agricultural production. Included in the activities of this subsystem is planning the selection of residential locations, commodities, technology, and farming patterns in order to increase primary agricultural production.

Subsystem of post harvest and agro industry have scope of activities not only on simple processing activities at transmigration level, but cover all activities ranging from post-harvest handling of agricultural products to advanced processing level. Thus the process of stripping, cleaning, extracting, milling, freezing, drying, quality improvement are included in the scope of post-harvest activities and agro-industries. Meanwhile, marketing subsystem includes the marketing of farm and agro-industry, both for the local market and for export. Monitoring and development of market information, both local and overseas markets , including one of the main activities of this subsystem.

The strategy for developing sustainable integrated agribusiness can be formulated as follows: First, improve the functional interconnection between subsystems so that each activity on each subsystem can take place continuously with high efficiency level. This means that the utilization pattern of natural resources, capital and human resources must be done efficiently and optimally at every node of activity and always refers to the market mechanism. Each stage of agribusiness should be able to distribute incentives to the actors involved with proportionally basis according to the input. Only with the creation of a fair incentive system then the whole agribusiness system can take place on an ongoing basis. Second, agribusiness development should be able to increase economic activity in transmigration area. The gap between the rapid growth of the workforce in the transmigration area and the limited economic activity in agricultural activities, especially farming, as well as the non- agricultural sector growth in the transmigration area has caused problems and socio-economic disparities between regions and between transmigration areas and cities. Agribusiness is an extension and expansion of economic activity in the agricultural sector which is expected to capture the labor force in the transmigration area and also increase the income of transmigration communities. Third, agribusiness development should be directed to the development of large-scale and small-scale business partners in a harmonious way, so that the added value of agribusiness can be enjoyed fairly by all actors. The agricultural production sector in transmigration areas is generally characterized by 
small farming scales. Thus large-scale agribusiness development must be able to attract small-scale enterprises in a mutually beneficial partnership concept.

\section{Conclusion}

Policies to support strategy above in many cases requires the cooperation and support of various agencies. In this case the Ministry of Village, Development of Disadvantage Regions and Transmigration together with other relevant Ministries/Agencies should strive to create objective conditions conducive to the development of agro-industry and marketing of agricultural products in transmigration areas. Large scale agribusiness in general has good capital, technology and management capability. The policy support required for the development of this business is more macro, such as the ease of export regulation for agro industry products, import inputs and production equipment, business licensing, taxation, trading, development of transportation and marketing infrastructure. Small and medium scale agro industry with various limitations, besides macro policy support also requires the development of human resources (transmigration), capital, technology, management and marketing to be more market-oriented and able to improve production efficiency. The linkage between large and small in an appropriate partnership environment becomes one of community development and transmigration area development strategies in the development of integrated agribusiness in a sustainable manner. Such thoughts and contributions can be expressed in the hope that the things mentioned above still need to be reviewed and developed further. Through the development of communities and transmigration areas, the government is working to reduce poverty and inequality in regional development. Successful development of communities and transmigration areas is expected to reduce poverty while also improving the living standards of transmigration and the surrounding population and can better state the development of the region. On ultimately the transmigration area is expected to function as a pull factor for attracting large numbers of spontaneous transmigration from densely populated or population-troubled areas.

\section{References}

Agus, Watung FRL, and A. Abbas Id. 1998. Implementation of problems of soil conservation measures in Indonesia. In Proc. 9th Annual Meeting of Asialand sloping Lands, Bogor, Indonesia. September 15-21 1997. IBSRAM, Bangkok.

Directorate General of Area Preparation and Transmigration Settlement Development 2015. Transmigration in the past, Present and Future Prospect. (In Indonesian)

Hermon, D. 2001. Studi Kontribusi Penggunaan Lahan dan Vegetasi Terhadap Karakteristik Epipedon. Tesis Magister. Program Pascasarjana Universitas Andalas Padang.

Hermon, D. 2009. Dinamika Permukiman dan Arahan Kebijakan Pengembangan Permukiman pada Kawasan Rawan Longsor di Kota Padang. Disertasi. IPB Bogor.

Hermon, D. 2010. Geografi Lingkungan: Perubahan Lingkungan Global. UNP Press.

Hermon, D. 2011. Studi Karakteristik Epipedon berdasarkan Penggunaan Lahan di Kecamatan X Koto Kabupaten Tanah Datar. Universitas Andalas.

Hermon, D. 2012. Mitigasi Bencana Hidrometeorlogi: Banjir, Longsor, Degradasi Lahan, Ekologi, Kekeringan, dan Puting Beliung. UNP Press. Padang.

Hermon, D. 2014. Impacts of Land Cover Change on Climate Trend in Padang Indonesia. Indonesian Journal of Geography. Volume 46. Issue 2. p: 138-142. Fakultas Geografi Universitas Gajah Mada.

Hermon, D. 2015. Geografi Bencana Alam. Jakarta: PT RajaGrafindo Persada.

Hermon, D. 2016. Mitigasi Perubahan Iklim. Rajawali Pers (Radjagrafindo).

Hermon, D. 2017. Climate Change Mitigation. Rajawali Pers (Radjagrafindo).

Hermon, D., P. Iskarni., O. Oktorie and R. Wilis. 2017. The Model of Land Cover Change into Settlement Area and Tin Mining and its Affecting Factors in Belitung Island, Indonesia. Journal of Environment and Earth Science. Volume 7 No. 6. p: 32-39. IISTE. 
Hermon, D., Ganefri., A. Putra and O. Oktorie. 2018. The Model of Mangrove Land Cover Change for the Estimation of Blue Carbon Stock Change in Belitung Island-Indonesia. International Journal of Applied Environmental Sciences. Volume 13. Issue 2. p: 191-202. Research India Publication.

Hermon, D., Ganefri, Erianjoni, I. Dewata, P. Iskarni and Alexander Syam. 2019. A Policy Model of Adaptation Mitigation and Social Risks The Volcano Eruption Disaster of Sinabung in Karo Regency-Indonesia. International Journal of GEOMATE. Volume 17. Issue 60. p: 190-196. Geomate International Society.

Hermon, D. 2019. Evaluation of Physical Development of The Coastal Tourism Regions on Tsunami Potentially Zones in Pariaman City-Indonesia. International Journal of GEOMATE. Volume 17. Issue 59. p: 189-196. Geomate International Society.

Iskandar, M (Editor). 2009. Transmigration can ! (In Indonesian)

Iskandar, H.A.M. 2010. Revitalization of Transmigration. (In Indonesian).

Ismail, IG, T. Alihamsyah, IPG Widjaja-Adhi, Suwarno, H. Tati, R. Tahir and DE Sianturi. 1993. Missing Research in Swampland (1985-1993). Development Contributions and Prospects. Tidal Land Agriculture and Swamps II Research Project. Food Crop Research and Development Center. Bogor. (In Indonesian)

Kurnia, U. 2001. Soil Conservation in Dried and Degraded Dry Land for Increased Soil Productivity. Proceedings of the Seminar on Management of Angled and Degraded Dry Land. Bogor, August 9-10, 2001. 35-46. (In Indonesian)

Minister of Village, Underdeveloped Region Development and Transmigration (2016; 2017; 2018). Minister Village, Underdeveloped Region Development and Transmigration Decrees number 9 of 2016, 91 of 2016, 104 of 2017, 118 of 2017, 71 of 2018, 106 of 2018, 115 of 2018 about Transmigration Area Appointment. (In Indonesian)

Oktorie, O. 2017. A Study of Landslide Areas Mitigation and Adaptation in Palupuah Subdistrict, Agam Regency, West Sumatra Province, Indonesia. Sumatra Journal of Disaster, Geography and Geography Education. Volume 1. Issue. 1. p: 43-49. Master Program of Geography Education.

Sardjadidjaja, R. 2005. Transmigration Blending and National Integration. Jakarta. P.T. Pustaka Surian Harapan. (In Indonesian)

Sinukaban, N. 2007. Soil and Water Conservation. Key to Sustainable Development. Directorate General of RLPS, Ministry of Forestry and Department of Soil and Land Resources, Bogor Agricultural University. (In Indonesian)

Sitorus, SRP. 2002. Potential and Problems of Marginal Imperata Land for Agricultural Use and Transmigration. Journal of Water, Land, Environment and Disaster Mitigation. 7 (1): 1-8. (In Indonesian)

Sukmana, S. 1995. Soil conservation techniques in overcoming the degradation of dryland agricultural land. P. 23-41 in Proceedings of the Land Research and Agro-Climate Results Discussion and Communication MeetingBook I Policy Papers. Cisarua, Bogor, September 26-28 1995. Puslittanak, Bogor. (In Indonesian)

Suriadikarta, DA and D. Setyorini. 2006. Technology for acid sulphate land management. In the Characteristics and Management of Swamp Land. Center for Research and Development of Agricultural Land Resources.Agricultural Research and Development Agency, Ministry of Agriculture. Bogor. P.117-150. (In Indonesian)

Widjaja-Adhi, GPA and T. Alihamsyah. 1998. Development of Tidal Land: Potential, Prospects and Constraints and Management Technology for Agriculture. Proceedings of the National Seminar and Annual Meeting of Komda HITI, December 16-17 1998. (In Indonesian)

Yusuf, A., E. Rusdi, N.Hasan and A.Taher. 1995. Study of Water, Potassium and Micro Nutrients on Rice in Deep Peatlands. In the Technology of Production and Development of Farming Systems in Swamp Land. Collection of results of research on ISDR-Integrated Swamp Agriculture Development Research Project. Agricultural Research Agency. (In Indonesian) 